\title{
The Geology of England - critical examples of Earth history - an overview
}

Mark A. Woods*, Jonathan R. Lee

British Geological Survey, Environmental Science Centre, Keyworth, Nottingham, NG12 5GG

*Corresponding Author: Mark A. Woods, email: maw@bgs.ac.uk

\begin{abstract}
Over the past one billion years, England has experienced a remarkable geological journey. At times it has formed part of ancient volcanic island arcs, mountain ranges and arid deserts; lain beneath deep oceans, shallow tropical seas, extensive coal swamps and vast ice sheets; been inhabited by the earliest complex life forms, dinosaurs, and finally, witnessed the evolution of humans to a level where they now utilise and change the natural environment to meet their societal and economic needs. Evidence of this journey is recorded in the landscape and the rocks and sediments beneath our feet, and this article provides an overview of these events and the themed contributions to this Special Issue of Proceedings of the Geologists' Association, which focuses on 'The Geology of England - critical examples of Earth History'. Rather than being a stratigraphic account of English geology, this paper and the Special Issue attempts to place the Geology of England within the broader context of key 'shifts' and 'tipping points' that have occurred during Earth History.
\end{abstract}

\section{Introduction}

England, together with the wider British Isles, is blessed with huge diversity of geology, reflected by the variety of natural landscapes and abundant geological resources that have underpinned economic growth during and since the Industrial Revolution. Industrialisation provided a practical impetus for better understanding the nature and pattern of the geological record, reflected by the publication in 1815 of the first geological map of Britain by William Smith (Winchester, 2001), and in 1835 by the founding of a national geological survey. Since the publication of Smith's map, our understanding of English geology has evolved in-parallel with major paradigm shifts (e.g. evolution, continental drift, plate tectonics, 'Ice Ages') in geological theory (Brenchley and Rawson, 2006). Now, through the Information Revolution disparate observations are increasingly being compiled to reveal new perspectives and insights into Earth-system processes.

Rather than attempting a stratigraphic review of the geological record of England, this Special Issue attempts to explore how the Geology of England provides examples for understanding regional geological successions within the context of much broader 'shifts' or 'tipping points' in Earth History. These key events produce a wide spectrum of geological responses, driving changes in earth surface processes, palaeogeography and palaeoenvironment. 'Process' and 'context' are two important themes that unify the articles in this Special Issue, allowing geological products (e.g. rock and sediment type, structure, geometry etc) and properties to be linked to large-scale causal mechanisms, and providing holistic understanding of regional geological successions. It also contributes to a better conceptual understanding of sub-surface geological heterogeneity; a broader appreciation of our geological heritage, and a greater knowledge of how geology (e.g. resources, hazards) influences society and our economy. 


\section{The geological history of England: a global context}

The events described in this Special Issue represent key phases through the one billion year geological history of England. Here we provide a broader perspective of that history to function as a framework within which the associated events and processes can be understood. It is a remarkable fact that such a small region as England and the wider British Isles preserves material from virtually every part of the geological column. Global plate tectonic reconstructions (http://www.scotese.com/) show that for much of its geological history, England was located close to rifted basin margins, and at other times phases of mountain building created new lines of structural weakness to accommodate the products of the next depositional cycle. This imparts a particular structural complexity, facilitating the possibility of local extensional tectonics and deposition even during phases of broad regional compression and uplift.

In the following sections of this overview paper we outline five key phases within the geological evolution of England: (1) Neoproterozoic to Early Paleozoic: England's foundations and the emergence of complex life; (2) Late Paleozoic to Early Mesozoic: coalescing continents; (3) Mesozoic rifting and epicontinental seas; (4) Cenozoic: exhumation and the transition to 'icehouse' climates; (5) Humans and Geology. Each phase is associated with significant 'shifts' or 'tipping points' in geological environments and processes which are described and linked to contributions (bold) in this Special Issue.

\subsection{Neoproterozoic to Early Paleozoic: England's foundations and the emergence of complex life}

The story of England's geological evolution can be traced back to the Neoproterozoic (1.0 Ga - $541 \mathrm{Ma}$ ). Rocks of this age form a complex collage of different structural blocks including recycled continental crust, oceanic crust and oceanic island arcs which collectively form England's basement geology (Pharoah et al., 1995, 1996; Pharoah, 1999, 2018; Beamish et al., 2016).

During the Neoproterozoic, England probably formed part of the Amazonian margin of the Gondwana supercontinent located at high southern latitudes and extending across the South Polar Region (Fig. 1, Late Neoproterozoic). In the Late Neoproterozoic (Ediacaran; 635 - 541 Ma) the first signs of complex life began to appear in the oceans, revealed as fossilised remains in rocks exposed at Charnwood Forest in the English Midlands (Fig.1(i)). Although first discovered in Newfoundland in 1868 by Alexander Murray, and later in Namibia (Gurich, 1933) and the Ediacara Hills in South Australia (Sprigg, 1947), the significance of these fossil discoveries was initially dismissed because of the assumption that they must represent Cambrian successions. It was only the discovery of the fossil Charnia at Charnwood Forest in Leicestershire, in rocks of undoubted Precambrian age, that the potential importance of the earlier discoveries was realised (Ford, 1958). For many years since that initial discovery the rocks of Charnwood Forest appeared to offer little insight into the nature of Late Neoproterozoic life, with just a few additional records of Charnia to add to the fossil inventory (Ford, 1980, 1999; Boynton and Ford, 1995; Antcliffe and Brasier, 2008). In recent years however, all this has changed, with the discovery of a much wider range of complex life forms in these rocks (Wilby et al., 2011, 2015; Howe et al., 2012; Kenchington et al., 2018). As Kenchington et al. (2018) reveal in their overview in this Special Issue, the Charnwood biota is not only historically significant for establishing the antiquity of these life forms, but new discoveries provide an updated context for understanding its evolution and diversity. This new work demonstrates that there are several dozen horizons within the succession where fossil remains occur, rather than just the few surfaces previously known (Kenchington et al., 2018). These have revealed new details of fossil morphology, and shed new light on the relationship with related and partly coeval biotas known from Newfoundland (Canada). Fossil diversity and density is much greater than previously thought at Charnwood, and there are new species 
that are not known in the Newfoundland biota and which may be strongly controlled by local environmental setting (Kenchington et al., 2018).

Rifting of the Gondwana continental margin during the Cambrian or Ordovician gave birth to the microcontinent of Avalonia, with England corresponding to the eastern part of this region (Pharoah et al., 1995, 1996; Pharoah, 1999; Beamish et al., 2016). For much of the Ordovician and Silurian, a partly emergent Avalonia drifted towards mid-southern hemisphere latitudes. Avalonia was flanked by deep basins to the north-west (lapetus Ocean), east (Tornquist Sea) and south-east (Rheic Ocean), and intermittently fringed by volcanic island arcs as the micro-continent began to collide and amalgamate with other crustal fragments (Smith and Thomas, 2015). By the Mid-Silurian the lapetus Ocean had closed and Avalonia was located around $30^{\circ} \mathrm{S}$ and had become accreted onto the southern margin of the Laurussia continental mass (Woodcock and Soper, 2006; Torsvik and Cocks, 2017). Evidence for this highly complex part of England's geological history is revealed by the geology of the Anglo-Brabant Massif (A-BM) situated beneath central and south-east England (Pharoah et al., 1993), reviewed in this Special Issue by Pharoah (2018). Early Paleozoic rocks that form the A-BM reveal a tripartite sequence that can be correlated with coeval sequences in Wales, Newfoundland and the northern Appalachians. These rocks demonstrate a south-west to north-east facies transition from shallow marine platform to deeper basinal sediments, and bear witness to voluminous igneous and volcanic activity associated with Ordovician subduction (Pharoah, 2018). Subsequent deformation by latest Silurian and Early Devonian tectonic events defined the A-BM as a distinct structural entity, which continued to exert influence on the development of accommodation space and patterns of sedimentation through the remaining Paleozoic and Mesozoic history of England (Pharoah, 2018).

\subsection{Late Paleozoic to Early Mesozoic: colliding continents}

During the Devonian, England experienced a warm to hot semi-arid climate on the subtropical southern fringe of Laurussia (Hillier and Williams, 2006; Kendall, 2017; Fig. 1 mid-Devonian), dominated by terrestrial environments. The evolution of rooted land plants caused atmospheric $\mathrm{CO}_{2}$ concentrations to decline, promoting relative landscape stabilisation (Kendall, 2017) and increased rates of chemical weathering (Baars, 2017) and soil development (Kendall, 2017). Variable patterns of syn- to post-orogenic terrestrial sedimentation to the north of the A-BM (Kendall, 2017) contrast with areas to the south where largely persistent marine and marginal marine conditions occurred (Torsvik and Cocks, 2017). The varied successions are revealed in structurally complex basins across south-west England (Leveridge and Hartley, 2006; Leveridge and Shail, 2011a, b; Leveridge, 2011; Whittaker and Leveridge, 2011) that bordered a tropical oceanic corridor (Rheic Ocean) separating Laurussia and Gondwana (Torsvik and Cocks, 2017; Fig. 1). A protracted (Devonian - Carboniferous) series of terrane and larger continental collisions along this oceanic margin are responsible for the Variscan Orogeny (Torsvik and Cocks, 2017).

In the early Carboniferous, back-arc extension associated with the Variscan subduction zone, caused rifting along pre-existing lines of structural weakness (Guion et al., 2000; Stone et al., 2010). This particularly affected areas north of the A-BM and shaped the typical block-and-basin structural fabric which was progressively infilled by early Carboniferous marine limestones and late Carboniferous (Westphalian Stephanian) delta plains (Guion et al., 2000; Waters and Davies, 2006; Stone et al., 2010; Fig. 1 Late Carboniferous). Occupying a broad equatorial swathe, these deltas were colonised by the iconic giant ferns, horsetails and club mosses of the coal swamp 'forests', the source of 'Coal Measures' deposits (Fielding, 1984; Waters et al., 1996; Waters and Davies, 2006).

The ecosystem diversity of the coal swamps, focussing particularly on the exceptionally well-preserved plant fossils from the Pennine Basin, is explored in this volume by Cleal (2018). Many of the floras 
represent a rather narrow range of environments, typically close to rivers where their remains would easily be transported to sites favourable for preservation, whereas the main part of the coal swamp was dominated by a single broad group of peat-forming plants (arborescent lycophytes) with root systems (Fig.1iii) adapted to waterlogged substrates (Cleal, 2018). Floral diversity can be correlated with frequency of marine flooding events and glacio-eustatic sea-level change linked to the expansion of southern hemisphere ice volume (Maynard and Leeder, 1992; Berner, 1997; Waters and Davies, 2006; Davies, 2008; Waters and Condon, 2012; Cleal, 2018). Although comparable in scale to modern day tropical rain forests, the diversity of the coal swamp ecosystem actually bears closer ecological comparison with modern mangrove swamps (Cleal, 2018).

Towards the end of the Westphalian, the climax of the Variscan Orogeny resulted in the final closure of oceanic basins separating Gondwana and Laurussia, eliminating the late Carboniferous deltaic ecosystem and creating the vast new supercontinent of Pangaea (Fig. 1, Triassic). England and the wider British Isles were located close to the centre of Pangaea (Torsvik and Cocks, 2017) with the interior of this supercontinent forming part of one of the 'great deserts of world history' (Smith and Taylor, 1992). However, almost as soon as Pangaea was created it began to break-apart (Ruffell and Shelton, 2000). The early stages of Atlantic rifting opened Permian and Triassic basins across England and the broader area of northwest Europe, which became infilled with a complex mixture of hypersaline, terrestrial and fluvial sediments (Coward, 1995; McKie and Williams, 2009; Fig. 1iv).

Making sense of the Triassic terrestrial successions has proved problematic, with a tendency to regard individual continental basins as having successions that reflected local depositional and structural controls. However, as Newell (2018) describes in this volume, there may be unifying lithological themes across basins that can be related to variable patterns of rifting associated with the break-up of Pangaea. New data reveals two intervals in the Early and Mid Triassic (Sherwood Sandstone Group; Fig. 1iv) when major, northward-flowing, long-distance river systems became established, separated by a succession of 'mixed facies' (e.g. fluvial/aeolian sandstones, mudstones, evaporites) (Newell, 2018). The 'mixed facies' are compartmentalised and disrupted by structure, suggesting that large-scale river system development occurred preferentially during periods of reduced rifting, with disruption of these systems and local patterns of sedimentation favoured by more active rifting phases (Newell, 2018).

\subsection{Mesozoic rifting and epicontinental seas}

By the Late Triassic and Early Jurassic, a combination of prolonged erosion and ongoing rifting and subsidence allowed the progressive encroachment and establishment of marine conditions across England, creating a network of islands surrounded by shallow and deeper water areas (Cope, 2006; Fig.1 Early Jurassic). Marine conditions persisted for much of the remaining Mesozoic (Hesselbo, 2000), and the A-BM continued to be an influential structural feature (Pharoah, 2018), particularly affecting palaeogeography and basin architecture. Thick successions were deposited in deeper subsiding basins and thinner successions, often cut by erosion surfaces, developed across more buoyant structural blocks (Hesselbo, 2000). These successions reflect a combination of local depositional architecture and its interaction with eustatic sea-level change and tectonic stresses associated with the continued breakup of Pangaea (Hesselbo and Jenkyns, 1998). Tectonic stresses drove the opening to the west of the central Atlantic Ocean in the Sinemurian (199.3 - 190.8 Ma; Torsvik and Cocks, 2017) and to the east, Mid Jurassic rifting of the North Sea Basin (Hesselbo, 2000). Across southern England, thrusts formed during the Variscan Orogeny became reactivated as large-scale basin-bounding listric structures, defining areas of rapid subsidence and deposition (Chadwick, 1986; Hesselbo, 2000). 
Within this complex array of facies some geological units stand out as marking globally-significant geological events that simultaneously affected many regions. These include the Toarcian Oceanic Anoxic Event (T-OAE, c. $183 \mathrm{Ma}$ ), marking a widespread period of marine anoxia and organic-rich shale deposition (Jenkyns and Clayton, 1997; Hesselbo et al., 2007; Kemp et al., 2011). In this Special Issue, the T-OAE in England is described by Thibault et al. (2018) based upon Early Jurassic strata that crop-out on the Yorkshire coast (Fig.1v). The T-OAE event is associated with the increased burial of carbon and the development of geochemical anomalies, including an enigmatic precursor anomaly at the Pleinsbachian/Toarcian boundary (Thibault et al., 2018). New data presented by this study is used as a proxy for understanding temporal patterns of basin geography and sea-level change which in-part link to astronomical climate forcing. Some geochemical and mineral indicators of anoxia appear to become disconnected, perhaps reflecting depletion in key elemental concentrations as a consequence of a severe and sustained reduction in oxygenation of marine environments.

Marine limestones and mudstones dominate the Late Jurassic in England, but by the Early Cretaceous globally low sea-levels and isostatic recovery following a period of crustal extension resulted in much of England experiencing terrestrial conditions (Chadwick 1985; Rawson, 2006). Exceptions were pockets of marine sediments marginal to the North Sea Basin and the fault-bounded basins developed on the fractured Variscan foreland south of the A-BM, where mixed fluvial and marine deposition continued (Rawson, 2006). The mixed sandstones and mudstones that form the bulk of the Early Cretaceous succession provide a record of the progressive marine flooding of southern and central England as global sea-levels progressively increased, eventually completely drowning the A-BM in the Albian for the first time in 300 million years (Hancock and Rawson, 1992; Gale, 2000a). By the Late Cretaceous, global sea-levels had risen to their highest levels during in the Phanerozoic (Fig.1 Late Cretaceous), driven by thermal anomalies in the upper mantle that boosted plate spreading rates and inflated mid-ocean ridge volumes, displacing water from marine basins onto adjacent continental margins (Gale, 2000b). England and much of the British Isles were submerged and blanketed with a thick pure-white limestone, the Chalk (Fig. 1vi). Chalk is a type of limestone formed predominantly from nannoplankton (coccolithophores) and about $10 \%$ foraminifera, which today is generally typical of open ocean-settings. However, during the Late Cretaceous, under the influence of a super-greenhouse climate and globally high sea levels, marine conditions and Chalk sedimentation extended across many previously emergent areas (Gale, 2000b).

The Chalk has been the subject of much research in recent years (Mortimore, 2014, and references therein), particularly the role of intra-Cretaceous tectonic events which is explored by a contribution to this Special Issue by Mortimore (2018). This paper reviews the European evidence for intra-Late Cretaceous (Subhercynian) tectonic events and their timing; the wider stress regime responsible for these events, and the extent to which they are manifest in the depositional development of Chalk successions across southern England. Mortimore (2018) suggests that the magnitude of these tectonic events has been underemphasised in English onshore successions, and that the combined effects of Atlantic opening and progressive convergence of the African and Eurasian plates provide a viable mechanism for accumulation of in-plane stresses, causing movement of fault networks across-which Chalk was being deposited (Mortimore, 2018).

\subsection{Cenozoic: exhumation and the transition to 'icehouse' climates}

The Cretaceous/Paleogene boundary is an important palaeogeographic 'tipping-point' across much of Britain and north-west Europe (Ziegler, 1988; Knox, 2010). It corresponds to a significant amplification of exhumation rates driven by the progressive convergence of the Eurasian-Iberian and African tectonic plates, culminating (in the Neogene) in the Alpine Orogeny (Stoker et al., 2005; Hillis et al., 2008; Holford et 
al., 2009; Lee et al., 2018). Britain was also affected by proximity to the Iceland Mantle Plume, causing crustal doming and thickening (Brodie and White, 1994) and accelerated exhumation across parts of western and northern Britain (Tiley et al., 2004; Arrowsmith et al., 2005; Williams et al., 2005). Later crustal rupture across this thermal anomaly allowed northward extension of Atlantic rifting between Greenland and Europe, an event associated with widespread volcanism and igneous intrusion along the north-west margin of the British Isles (the British Tertiary Igneous Province; Mussett et al., 1988), and is reflected by ash layers preserved in Paleogene deposits across parts of southern and eastern England (Anderton, 2000; King, 2006; Aldiss, 2015).

Collectively, exhumation driven by Alpine compression and/or mantle plume led to the erosion of Mesozoic cover rocks, which are now largely absent from northern England (Huuse and Clausen, 2001; Westaway, 2010). However, the relative significance of these mechanisms on landscape development in England remains controversial (e.g. Cope, 1994, 1995; Thomson, 1995), and is discussed in this Special Issue by Gale and Lovell (2018). This paper focusses specifically on southern England, a region previously considered by many to be located beyond the isostatic influence of the Iceland Mantle Plume. Gale and Lovell (2018) demonstrate several hundred metres of erosion of the Chalk of southern England during the Paleogene, with patterns of denudation comparable with those expected across the south-east flank of a thermal swell, with its centre located to the north-west. More generally, this thermal uplift, and associated magmatic underplating, may be the reason for the strong south-eastward regional tilting and distinctive NE - SW strike of Mesozoic and Cenozoic units across south-east England (Gale and Lovell, 2018). This tilting strongly shaped the complex pattern of Paleogene deposition into the North Sea Basin by controlling sediment supply and accommodation space (King, 2006).

The Early Neogene (Fig. 1 Miocene) is dominated by the impact of the Alpine Orogeny and the final closure of the Tethys Ocean to the south. Across much of Britain, the North Sea, Atlantic margin and Fennoscandia it resulted in accelerated uplift and the development of an extensive Miocene-age unconformity (Walsh, 1999; Huuse and Clausen, 2001; Stoker, 2002). South of the A-BM, uplift was focussed on basin-margin faults that were originally thrusts generated during the earlier Variscan Orogeny. In some places, uplift along these faults created broad anticlines and synclines, and elsewhere produced sharp monoclines and periclines (Barton et al., 2011; Fig. 1). Examples of reactivated Variscan faults in England include the Isle of Wight - Purbeck Monocline and associated Purbeck - Wight Fault Zone, seen on the World Heritage Coast of Dorset (Fig.1vii) and described and discussed in this volume by Westhead et al. (2018) using newly available offshore data. The authors identify contrasting structural styles that relate to positions either in the main shear zone or hangingwall segment of the structure, and associate the famous 'Lulworth Crumple' (Fig. 1vii) with a northerly inclined thrust, allowing its reinterpretation as a product of southward shear antithetic to the main Purbeck-Wight Fault Zone.

In addition to ongoing tectonic influences, the Cenozoic is also notable for the deterioration of global climate from the 'greenhouse climates' that define the Early Paleogene, through to the 'icehouse climates' that have characterised the interval from the beginning of the Oligocene (33.9 Ma) to the present day (Zachos et al., 2001; Fig. 1, Quaternary). The beginning of the Oligocene marks the onset of widespread glaciation in Antarctica (Zachos et al., 2001), with the inception and step-wise up-scaling of northern hemisphere glaciation following during the Neogene and Quaternary that culminated in the establishment of regular cyclical phases of glaciation (Ehlers and Gibbard, 2007; Lisiecki and Raymo, 2007; Böse et al., 2012; Fig.1viii). The precise drivers of this climatic deterioration are likely to reflect the complex interaction of global palaeogeography (driven by tectonics) and ocean circulation (Haug and Tiedemann, 1998; Hotinski and Troggweiler, 2003; Montes et al., 2015) amplified by variations in solar insolation driven by orbital forcing (Shackleton, 1987). 
Across England (and the wider British Isles), the impact of tectonics and climate on landscape evolution during the Neogene and Quaternary are examined in this volume by the contribution from Lee et al.

(2018). By the Late Neogene, the impact of Alpine compression and plume-related tectonics had either ceased or waned markedly and climate-driven denudational isostasy became the principal tectonic driver of landscape evolution (Lee et al., 2018). The significance of this process amplified progressively during the Late Neogene and Quaternary as the glacial-interglacial cyclicity strengthened (Lee et al., 2018). Whilst the geological record from England provides clear evidence for long-term climate variability, there are hints for abrupt (millennial to centennial scale) climatic events although these can realistically only be clearly expressed into a regional framework during the Last Glacial Interglacial Transition and early Holocene phases of climate change (Lee et al., 2018).

\subsection{Humans and Geology}

Humans have periodically occupied the English landscape for perhaps as long as $0.9 \mathrm{Ma}$ (Parfitt et al., 2010), increasingly going beyond adaptation to it and showing expanding capacity to both utilise and alter the environment (Steffen et al., 2007). This has led some to speculate that the changes we have wrought on the Earth are of sufficient environmental significance for a new geological age to be recognised - the 'Anthropocene' (Zalasiewicz et al., 2008; Lewis and Maslin, 2015; Waters et al., 2016; Fig. 1 Anthropocene). This topic is explored in this volume by Zalasiewicz et al. (2018) in the context of England's long history of industrial development, including the lines of evidence that justify its recognition and the features that will preserve and signify its presence in the geological record. These features include changing atmospheric composition (Fig. 1ix), sediment geochemistry, novel materials (e.g. plastics/concrete) and radionuclides, much found in natural environments including lakes, rivers, coastal and marine habitats, but also including mined and excavated areas associated with significant development of 'artificial ground' (Zalasiewicz et al., 2018).

For the Anthropocene, as with any of the formally-recognised geological periods, it is important to acknowledge that some outcrop successions better or more fully preserve the evidence of geological processes than others. This is partly because palaeoenvironmental variability means that different geographical areas acquire different geological signatures as a function of process and preservation, and also because the interpretation of the geological record naturally evolves through time as the subject advances. For this reason the geological community needs to consider policies for conserving sites that provide the fundamental evidence for our scientific understanding of the geological record (Gray, 2008; Burek, 2012). This Special Issue therefore concludes with a discussion by Brown et al. (2018) about how geoconservation policy has evolved in partnership with the geoscience community in England to safe-guard our geological heritage. According to Brown et al. (2018), the role that the geoscience community has had in geoconservation cannot be underplayed. These activities range from systematic auditing of sites to establish the breadth of geodiversity in England to ongoing site and landscape management and safeguarding, as well as raising awareness of geoconservation to planners and decision makers and the public through outreach activities and education (Prosser et al., 2011; Gray et al., 2013; Prosser, 2013; Brown et al., 2018).

\section{Conclusions}

England's diversity of geology and landscape provides evidence of a rich and dynamic Earth History, punctuated by key 'shifts' and 'tipping points' in environmental processes.

- Neoproterozoic and Early Paleozoic rocks, forming the foundation geology of England, represent environments developed at the margin of the Gondwana supercontinent and the later ribbon-like micro-continent of Avalonia that rifted from its margin. This phase of England's geological history is 
revealed in successions forming deep structural levels in the Anglo-Brabant Massif (Pharaoh, 2018) and exposed at Charnwood Forest in the English Midlands (Kenchington et al., 2018).

- The successions at Charnwood Forest contain evidence for some of the earliest (Late Neoproterozoic) complex life forms on the planet, comparable to famous sites in North America. New research is revealing insights into the complexity of this fossil biota and the controls on its diversity and evolution (Kenchington et al., 2018).

- Throughout much of the Late Paleozoic England straddled the tropics and equatorial region forming part of the Laurussia continental block. During the late Carboniferous, much of England comprised extensive coal swamp forests. The ecosystem diversity of these coal swamps is explored by Cleal (2018) and reveals strong links to glacio-eustatic sea-level trends connected to the expansion of ice caps in the southern hemisphere.

- Towards the end of the Carboniferous, continued uplift (Variscan Orogeny) and coalescence of continental blocks formed the Pangaea supercontinent, which almost immediately began to breakapart under the influence of extensional stresses associated with the initiation of Atlantic opening. Complex patterns of continental basin sedimentation (hypersaline, terrestrial and fluvial) in arid and semi-arid desert environments persisted through the Permian and Early and Mid Triassic. The relationship of Triassic rivers to the complex basinal structure and patterns of continental rifting is discussed by Newell (2018).

- Much of the Mesozoic, from the Late Triassic through to end-Cretaceous, represents a time when largely marine conditions prevailed across England, as tensional stresses related to ongoing Atlantic rifting created extensive epicontinental basins. Global ecosystem perturbations, such as the Toarcian Ocean Anoxic Event, described by Thibault et al. (2018), punctuate the geological record. The AngloBrabant Massif continued to have a fundamental control on palaeogeography, influencing patterns of deposition across south-east England (Pharaoh, 2018), and major structural lineaments created by Caledonian and Variscan orogenic cycles exerted significant influence on patterns of Chalk sedimentation (Mortimore, 2018).

- In the Cenozoic, England is increasingly influenced by tectonic activity linked to the closure of the Tethys Ocean separating the Eurasian and African continental blocks, and magmatic activity associated with proximity of Britain to the Iceland Mantle Plume. The role of thermally-driven uplift in southern England is explored by Gale and Lovell (2018), whilst Westhead et al. (2018) make a case study of a major Alpine inversion structure that slices through the Dorset and East Devon World Heritage Coast.

- Progressive climatic deterioration and the transition to 'icehouse climates' was a significant control on landscape evolution during the Late Neogene and Quaternary. Climatic denudation of the landscape ultimately replaced tectonics as the primary driver of landscape change in England and this is evaluated by Lee et al. (2018).

- In the late Quaternary, humans play an increasingly influential role in the Geology of England, actively utilising and changing environments for societal and economic gain, and perhaps defining a new geological era - the 'Anthropocene'. The basis and evidence for the 'Anthropocene' is discussed in a paper by Zalasiewicz et al. (2018), and a further paper by Brown et al. (2018) emphasises the importance of conserving evidence of the geological record for future study, and the significant role that the geoscience community has in promoting awareness and recording information.

\section{Acknowledgments}

The authors wish to thank the various contributors to this Special Issue for their commitment and dedication in providing material for this publication. In addition, the Editors in Chief, Jim Rose and Malcolm Hart, are thanked for their support and patience during the compilation of the Special Issue and to Milena 
Prevost, Liz Wileman and Tim Horscroft (Elsevier) for their guidance and help with production. C. R. Scotese (Paleomap Project; http://www.scotese.com/) and Prof. Dietmar Müller (University of Sydney and Earthbyte Project; https://www.earthbyte.org) are thanked for permission to adapt palaeogeographical maps used for Figure 1 of this paper. This paper is published with the permission of the Executive Director of the British Geological Survey (NERC).

\section{References}

Aldiss, D. T., 2015. Palaeogene. In: Lee, J. R., Woods, M. A., Moorlock, B. S. P. (eds), British Regional Geology: East Anglia (Fifth edition), British Geological Survey, Nottingham, 81-89.

Antcliffe, J.B., Brasier, M.D., 2008. Charnia at 50: development models for Ediacaran fronds. Paleontology $51,11-26$.

Anderton, R., 2000. Tertiary events: the North Atlantic plume and Alpine pulses. In: Woodcock, N., Strachan, R. (eds), Geological History of Britain and Ireland, Blackwell Science, Oxford, 374 - 391.

Arrowsmith, S.J., Kendall, M., White, N., Van Decar, J.C., Booth, D.C., 2005. Seismic imaging of a hot upwelling beneath the British Isles. Geology 33, 345-348.

Baars, C., 2017. Review of plant evolution and its effect on climate during the time of the Old Red Sandstone. Proceedings of the Geologists' Association 128, 431-437.

Barton, C. M., Woods, M. A., Bristow, C. R., Newell, A. J., Westhead, R. K., Evans, D. J., Kirby, G. A., Warrington, G., 2011. Geology of south Dorset and south-east Devon and its World Heritage Coast. Special Memoir of the British Geological Survey.

Beamish, D., Kimbell, G., Pharoah, T.C., 2016. The deep crustal magnetic structure of Britain. Proceedings of the Geologists' Association 127, 647-663.

Berner, R. A., 1997. The Rise of Plants and Their Effect on Weathering and Atmospheric $\mathrm{CO}_{2}$. Science 276, 544-546.

Böse, M., Lüthgens, C., Lee, J.R., Rose, J., 2012. Quaternary glaciations of northern Europe. Quaternary Science Reviews 44, 1-25.

Boynton, H.E., Ford, T.D., 1995. Ediacaran fossils from the Precambrian (Charnian Supergroup) of Charnwood Forest, Leicestershire, England. Mercian Geologist 13, 165-182.

Brenchley, P. J., Rawson, P. F. (eds), The Geology of England and Wales (Second edition), The Geological Society, London.

Brodie. J., White, N. 1994. Sedimentary basin inversion caused by igneous underplating: northwest European continental shelf. Geology 22, 147-150.

Brown, E. J., Evans, D. H., Larwood, J. G., Prosser, C. D., Townley, H. C., 2018. Geoconservation and geoscience in England: a mutually beneficial relationship. Proceedings of the Geologists' Association 129, \#\#\# - \#\#\#.

Burek, C.V., 2012. The importance of Quaternary geoconservation. Quarternary Newsletter 126, 25-33.

Chadwick, R. A., 1986. Extension tectonics in the Wessex basin, southern England. Journal of the Geological Society, London 143, 465-488. 
Chadwick, R. A., 1985. End Jurassic - early Cretaceous sedimentation and subsidence (late Portlandian to Barremian), and the late-Cimmerian unconformity. In: Whittaker, A. (ed.), Atlas of onshore sedimentary basins in England and Wales: post-Carboniferous tectonics and stratigraphy, 52-56, Blackie, Glasgow.

Cleal, C. J., 2018. The Carboniferous coal swamp floras of England. Proceedings of the Geologists' Association 129, \#\#\# - \#\#\#.

Coward, M.P., 1995. Structural and tectonic setting of the Permo-Triassic basins of northwest Europe, In: Boldy, S.A.R. (Ed.), Permian and Triassic Rifting in Northwest Europe. Geological Society, London, Special Publications, London, pp. 7-39.

Steffen, W., Crutzen, P.J., McNeill, J.R., 2007. The Anthropocene: are humans now overwhelming the great forces of nature. AMBIO: A Journal of the Human Environment 36, 614-621.

Davies, S.J., 2008. The record of Carboniferous sea-level change in low-latitude sedimentary successions from Britain and Ireland during the onset of the late Paleozoic ice age, In: Fielding, C.R., Frank, T.D., Isbell, J.L. (Eds.), Resolving the Late Paleozoic Ice Age in Time and Space. Geological Society of America, pp. 187204.

Dèzes, P., Schmid, S., Ziegler, P., 2004. Evolution of the European Cenozoic Rift System: interaction of the Alpine and Pyrenean orogens with their foreland lithosphere. Tectonophysics 389, 1-33.

Ehlers, J., Gibbard, P.L., 2007. The extent and chronology of Cenozoic Global Glaciation. Quaternary International 164-165, 6-20.

Fielding, C.R., 1984. A coal depositional model for the Durham Coal Measures of NE England. Journal of the Geological Society 141, 919-931.

Ford T. D., 1958. Pre-Cambrian fossils from Charnwood Forest. Proceedings of the Yorkshire Geological Society 31, 211-217.

Ford, T.D., 1980. The Ediacaran fossils of Charnwood Forest, Leicestershire. Proceedings of the Geologists' Association 91, 81-83.

Ford, T.D., 1999. Topics The Precambrian fossils of Charnwood Forest. Geology Today 15, 230-234.

Cope, J.C.W., 1994. A latest Cretaceous hotspot and the southeasterly tilt of Britain. Journal of the Geological Society 151, 905-908.

Cope, J.C.W., 1995. Reply to discussion by K. Thomson on paper by J.C.W. Cope: A latest hotspot and the south-easterly tilt of Britain. Journal of the Geological Society, 152, 729-731.

Cope, J. C. W., 2006. 14 Jurassic: the returning seas. In: Brenchley, P. J., Rawson, P. F. (eds), The Geology of England and Wales (2nd edition), 325-363, The Geological Society: London.

Gale, A. S., Lovell, B. 2018. The Cretaceous - Paleogene unconformity in England: uplift and erosion related to the Iceland mantle plume. Proceedings of the Geologists' Association 129, \#\#\#-\#\#\#.

Gale, A. S., 2000a. 18 Early Cretaceous: rifting and sedimentation before the flood. In: Woodcock, N., Strachan, R. (eds), Geological History of Britain and Ireland, Oxford, Blackwell Science, 339-355. 
Gale, A. S., 2000b. 19 Late Cretaceous to Early Tertiary pelagic deposits: deposition on greenhouse Earth. In: Woodcock, N., Strachan, R. (eds), Geological History of Britain and Ireland, Blackwell Science, Oxford, 356-373.

Gray, M., 2008. Geodiversity: developing the paradigm. Proceedings of the Geologists' Association 119, 287 $-298$.

Gray, M., Gordon, J.E., Brown, E.J., 2013. Geodiversity and the ecosystem approach: the contribution of geoscience in delivering integrated environmental management. Proceedings of the Geologists' Association $124,659-673$.

Guion, P. D., Gutteridge, P., Davies, S. J., 2000. 14 Carboniferous sedimentation and volcanism on the Laurussian margin. In: Woodcock, N., Strachan, R. (eds), Geological History of Britain and Ireland, 227-270, Blackwell Science, Oxford.

Gürich, G., 1933. Die Kuibis-Fossilien der Nama-Formation von Südwestafrika. Paläontologische Zeitschrift 15, 137-155.

Hancock, J. M., Rawson, P. F., 1992. Cretaceous. In: Cope, J. C. W., Ingham, J. K., Rawson, P. F. (eds), Atlas of Palaeogeography and Lithofacies, Memoir 13, The Geological Society, London, 131-139.

Haug, G. H., Tiedemann, R., 1998. Effect of the formation of the Isthmus of Panama on Atlantic Ocean thermohaline circulation, Nature 393, 673-676.

Hillier, R. D., Williams, B. P. J., 2006. 8 The alluvial Old Red Sandstone: fluvial basins. In: Brenchley, P. J., Rawson, P. F. (eds), The Geology of England and Wales (Second edition), The Geological Society, London, 155-171.

Hesselbo, S. P., 2000. 17 Late Triassic and Jurassic: disintegrating Pangaea. In: Woodcock, N., Strachan, R. (eds), Geological History of Britain and Ireland, $314-338$, Blackwell Science, Oxford.

Hesselbo, S. P., Jenkyns, H. C., 1998. British Lower Jurassic Sequence Stratigraphy. In: Sequence stratigraphy of European basins, Jaquin, T., De Graciansky, P., Hardenbol, J. (eds), Society of Economic Palaeontologists and Mineralogists, Special Publication 60, 561-581.

Hesselbo, S.P., Jenkyns, H.C., Duarte, L.V., Oliveira, L.C., 2007. Carbon-isotope record of the Early Jurassic (Toarcian) Oceanic Anoxic Event from fossil wood and marine carbonate (Lusitanian Basin, Portugal). Earth and Planetary Science Letters 253, 455-470.

Hotinski, R. M., Toggweiler, J. R., 2003. Impact of a Tethyan circumglobal passage on ocean heat transport and "equable" climates. Paleoceanography 18, 1007.

Howe, M. P. A., Evans, M., Carney, J. N., Wilby, P. R., 2012. New perspectives on the globally important Ediacaran fossil discoveries in Charnwood Forest, UK: Harley's 1848 prequel to Ford (1958). Proceedings of the Yorkshire Geological Society 59, 137-144.

Huuse, M., Clausen, O.R., 2001. Morphology and origin of major Cenozoic sequence boundaries in the eastern North Sea Basin: top Eocene, near-top Oligocene and the Mid-Miocene unconformity. Basin Research 13, 17-41. 
Jenkyns, H.C., Clayton, C.J., 1997. Lower Jurassic epicontinental carbonates and mudstones from England and Wales: chemostratigraphic signals and the early Toarcian anoxic event. Sedimentology 44, 687-706.

Kemp, D.B., Coe, A.L., Cohen, A.S., Weedon, G.P., 2011. Astronomical forcing and chronology of the early Toarcian (Early Jurassic) oceanic anoxic event in Yorkshire, UK. Paleoceanography 26, PA4210.

Kenchington, C. G., Harris, S. J., Vixseboxse, P. B., Pickup, C., Wilby, P., 2018. The Ediacaran fossils of Charnwood Forest: shining new light on a major biological revolution. Proceedings of the Geologists' Association 129, \#\#\# - \#\#\#.

Kendall, R.S,. 2017. The Old Red Sandstone of Britain and Ireland - a review. Proceedings of the Geologists' Association 128, 409-421.

King, C., 2006. 16 Paleogene and Neogene uplift and cooling climate. In: Brenchley, P. J., Rawson, P. F. (eds), The Geology of England and Wales (Second edition), 395-427, The Geological Society, London.

Knox, R.W.O.B., Bosch, J.H.A., Rasmussen, E.S., Heilmann-Clausen, C., Hiss, M., De Lugt, I.R., Kasiński, J., King, C., Köthe, A., Słodkowska, B., Standke, K., Vandenberghe, N., 2010. Cenozoic, In: Doornenbal, J.C., Stevenson, A.G. (Eds.), Petroleum geological atlas of the Southern Permain Basin area. EAGE Publications b.v., Houten, pp. 211-223.

Lee, J. R., Candy, I., Haslam, R., 2018. The Neogene and Quaternary of England: landscape evolution, tectonics, climate change and their expression in the geological record. Proceedings of the Geologists' Association 129, \#\#\# - \#\#\#.

Leveridge, B. E. 2011. The Looe, South Devon and Tavy basins: the Devonian rifted passive margin successions. Proceedings of the Geologists' Association 122, 616-717.

Leveridge, B. E., Hartley, A. J., 2006. 10 The Variscan Orogeny: the development and deformation of Devonian/Carboniferous basins in SW England and South Wales. In: Brenchley, P. J., Rawson, P. F. (eds), The Geology of England and Wales (Second edition), The Geological Society, London, 225-255.

Leveridge, B. E., Shail, R. K., 2011a. The marine Devonian stratigraphy of Great Britain. Proceedings of the Geologists' Association 122, 540-567.

Leveridge, B. E., Shail, R. K. 2011b. The Gramscatho basin, south Cornwall, UK: Devonian active margin successions. Proceedings of the Geologists' Association 122, 568-615.

Lewis, S.L., Maslin, M.A., 2015. Defining the Anthropocene 519, 171-180.

Lisiecki, L.E., Raymo, M.E., 2007. Plio-Pleistocene climate evolution: trends and transitions in glacial cycle dynamics. Quaternary Science Reviews 26, 56-69.

Maynard, J.R., Leeder, M.R., 1992. On the periodicity and magnitude of Late Carboniferous glacio-eustatie sea-level changes. Journal of the Geological Society 149, 303-311.

McKie, T., Williams, B., 2009. Triassic palaeogeography and fluvial dispersal across the northwest European Basins. Geological Journal 44, 711-741.

Montes, C., Cardona, A., Jaramillo, C., Pardo, A., Silva, J. C., Valencia, V., Ayala, C., Péréz-Angel, L. C., Rodriguez-Parra, L. A., Ramirez, V., Niňo, H,. 2015. Middle Miocene closure of the Central American Seaway, Science 348, 226-229. 
Mortimore, R. N., 2018. Late Cretaceous sediment-tectonic events in NW Europe. Proceedings of the Geologists' Association 129, \#\#\# - \#\#\#.

Mortimore, R. N., 2014. Logging the Chalk. Whittles Publishing, Caithness, 317pp.

Mussett, A.E., Dagley, P., Skelhorn, R.R., 1988. Time and duration of activity in the British Tertiary Igneous Province, In: Morton, A.C., Parson, L.M. (Eds.), Early Tertiary Volcanism and the Opening of the NE Atlantic. Geological Society Special Publications, London, pp. 337-348.

Newell, A. J., 2018. Rifts, rivers and climate recovery: a new model for the Triassic of England. Proceedings of the Geologists' Association 129, \#\#\# - \#\#\#.

Parfitt, S.A., Ashton, N.M., Lewis, S.G., Abel, R.L., Coope, G.R., Field, M.H., Gale, R., Hoare, P.G., Larkin, N.R., Lewis, M.D., Karloukovski, V., Maher, B.A., Peglar, S.M., Preece, R.C., Whittaker, J.E., Stringer, C.B., 2010. Early Pleistocene human occupation at the edge of the boreal zone in northwest Europe. Nature 466, 229233.

Pharaoh, T.C., 1999. Palaeozoic terranes and their lithospheric boundaries within the Trans-European Suture Zone (TESZ): a review. Tectonophysics 314, 17-41.

Pharaoh, T. C., 2018. The Anglo-Brabant Massif: persistent but enigmatic palaeo-relief at the heart of western Europe. Proceedings of the Geologists' Association 129, \#\#\# - \#\#\#.

Pharaoh, T. C., Molyneux, S. G., Merriman, R. J., Lee, M. K., Verniers, J., 1993. The Caledonides of the AngloBrabant Massif reviewed. Geological Magazine 130, 561-562.

Pharaoh, T., England, R., Lee, M., 1995. The concealed Caledonide basement of eastern England and the southern North Sea-a review. Studia Geophysica et Geodaetica 39, 330-346.

Pharoah, T.C., Morris, J., Long, C.B., Ryan, P.D., 1996. The Tectonic Map of Britain, Ireland and Adjacent Areas. Sheet 1: 1500000 Scale. British Geological Survey and Geological Survey of Ireland.

Prosser, C.D., 2013. Our rich and varied geoconservation portfolio: the foundation for the future. Proceedings of the Geologists' Association 124, 568-580.

Prosser, C.D., Bridgland, D.R., Brown, E.J., Larwood, J.G., 2011. Geoconservation for science and society: challenges and opportunities. Proceedings of the Geologists' Association 122, 337-342.

Rawson, P. F., 2006. 15 Cretaceous: sea levels peak as the North Atlantic opens. In: Brenchley, P. J., Rawson, P. F. (eds), The Geology of England and Wales (Second edition), The Geological Society, London, 365-393.

Ruffell, A. H., Shelton, R. G. 2000., 16 Permian to Late Triassic post-orogenic collapse, early Atlantic rifting, deserts, evaporating seas, and mass extinctions. In: Woodcock, N., Strachan, R. (eds), Geological History of Britain and Ireland, Blackwell Science, Oxford, 297-313.

Scotese, C. R., 2002. http://www.scotese.com/ , (PALEOMAP website).

Scotese, C. R. 2016. Tutorial: PALEOMAP Paleoatlas for GPlates and the PaleoData Plotter Program, http://www.earthbyte.org/paleomap-paleoatlas-for-gplates/

Shackleton, N.J., 1987. Oxygen isotopes, ice volume and sea level. Quaternary Science Reviews 6, $183-190$. 
Smith, D. B., Taylor, J. C. M., 1992. Permian. In: Cope, J. C. W., Ingham, J. K., Rawson, P. F. (eds), Atlas of Palaeogeography and Lithofacies, Memoir 13, 87-96, The Geological Society, London.

Smith, N. J. P., Thomas, C. W., 2015. Concealed geology. In: Lee, J. R.,Woods, M. A., Moorlock, B. S. P. (eds), British Regional Geology: East Anglia (Fifth edition), 18-31, British Geological Survey, Nottingham.

Sprigg, R. C., 1947. Early Cambrian "jellyfishes" of Ediacara, South Australia and Mount John, Kimberly District, Western Australia". Transactions of the Royal Society of South Australia 73, 72-99.

Stoker, M.S., 2002. Late Neogene development of the UK Atlantic margin. In: Doré, A. G.D., Cartwright, J., Stoker, M.S., Turner, J.P., White, N. (Eds.), Exhumation of the North Atlantic Margin: Timing, Mechanisms and Implications for Petroleum Exploration, vol.196. Geological Society of London, Special Publication, 313329.

Stoker, M.S., Hoult, R.J., Nielsen, T., Hjelstuen, B.O., Laberg, J.S., Shannon, P.M., Praeg, D., Mathiesen, A., van Weering, T.C.E., McDonnell, A., 2005. Sedimentary and oceanographic responses to early Neogene compression on the NW European margin. Marine and Petroleum Geology 22, 1031-1044.

Stone, P., Millward, D., Young, B., Merritt, J. W., Clark, S. M., McCormac, M, Lawrence, D. J. D., 2010. British Regional Geology: Northern England (Fifth edition). British Geological Survey, Nottingham.

Thibault, N., Ruhl, M., Ullman, C. V., Korte, C., Kemp, D. B., Gröcke, D. R., Hesselbo, S. P., 2018. The wider context of the Lower Jurassic Toarcian Oceanic Anoxic Event in Yorkshire coastal outcrops, UK. Proceedings of the Geologists' Association 129, \#\#\# - \#\#\#.

Tiley, R., White, N., Al-Kindi, S., 2004. Linking Paleogene denudation and magmatic underplating beneath the British Isles. Geological Magazine 141, 345-351.

Torsvik, T. H., Cocks, L. R. M., 2017. Earth History and Palaeogeography, Cambridge University Press, Cambridge, 317pp.

Walsh, P.T., 1999. Pre-Pleistocene geomorphological evolution fo West Cornwall, In: Scourse, J.D., Furze, M.F.A. (Eds.), The Quaternary of West Cornwall, Field Guide. Quaternary Research Association, London, pp. 10-26.

Waters, C.N., Aitkenhead, N., Jones, N.S., Chisholm, J.I., 1996. Late Carboniferous stratigraphy and sedimentology of the Bradford area, and its implications for the regional geology of northern England. Proceedings of the Yorkshire Geological and Polytechnic Society 51, 87-101.

Waters, C. N., Davies, S. J., 2006. 9 Carboniferous: extensional basins, advancing deltas and coal swamps. In: Brenchley, P. J., Rawson, P. F. (eds), The Geology of England and Wales (Second edition), The Geological Society, London, 173-223.

Waters, C.N., Condon, D.J., 2012. Nature and timing of Late Mississippian to Mid-Pennsylvanian glacioeustatic sea-level changes of the Pennine Basin, UK. Journal of the Geological Society 169, 37-51.

Waters, C.N., Zalasiewicz, J., Summerhayes, C., Barnosky, A.D., Poirier, C., Gałuszka, A., Cearreta, A., Edgeworth, M., Ellis, E.C., Ellis, M., Jeandel, C., Leinfelder, R., McNeill, J.R., Richter, D.d., Steffen, W., Syvitski, J., Vidas, D., Wagreich, M., Williams, M., Zhisheng, A., Grinevald, J., Odada, E., Oreskes, N., Wolfe, A.P., 2016. The Anthropocene is functionally and stratigraphically distinct from the Holocene. Science 351, 137-148. 
Westhead, R. K., McCarthy, D., Collier, J. S., Sanderson, D. J., 2018. Spatial variability of the Purbeck - Wight Fault Zone - a long-lived tectonic element in the southern UK. Proceedings of the Geologists' Association 129, \#\#\# - \#\#\#.

Whittaker, A., Leveridge, B. E., 2011. The North Devon Basin: a Devonian passive margin shelf succession. Proceedings of the Geologists' Association 122, 718-744.

Wilby, P.R., Carney, J.N., Howe, M.P.A., 2011. A rich Ediacaran assemblage from eastern Avalonia: Evidence of early widespread diversity in the deep ocean. Geology 39, 655-658.

Wilby, P.R., Kenchington, C.G., Wilby, R.L., 2015. Role of low intensity environmental disturbance in structuring the earliest (Ediacaran) macrobenthic tiered communities. Palaeogeography, Palaeoclimatology, Palaeoecology 434, 14-27.

Williams, G.A., Turner, J.P., Holford, S.P., 2005. Inversion and exhumation of the St. George's Channel basin, offshore Wales, UK. Journal of the Geological Society 162, 97-110.

Winchester, S., 2001. The Map that changed the World: William Smith and the Birth of Modern Geology. Harper Collins, New York.

Zachos, J.C., Pagani, M., Sloan, L., Thomas, E., Billips, K., 2001. Trends, rhythms and aberration in global climate from $65 \mathrm{Ma}$ to present. Science 27, 686-693.

Zalasiewicz, J., Williams, M., Smith, A., Barry, T.L., Coe, A.L., Bown, P.R., Brenchley, P., Cantrill, D., Gale, A., Gibbard, P., Gregory, F.J., Hounslow, M.W., Kerr, A.C., Pearson, P., Knox, R.O.B., Powell, J.H., Waters, C., Marshall, J., Oates, M., Rawson, P.F., Stone, P., 2008. Are we now living in the Anthropocene? GSA Today $18,4-8$.

Zalasiewicz, J., Waters, C., Williams, M., Aldridge, D. C., Wilkinson, I. P., 2018. The stratigraphical signature of the Anthropocene in England and its wider context. Proceedings of the Geologists' Association 129, \#\#\# \#\#\#.

Ziegler, P.A., 1988. Evolution of the Arctic-North Atlantic and the western Tethys - a visual presentation of a series of paleogeographic-paleotectonic maps. American Association of Petroleum Geologists Memoir 43, 164-196.

Ziegler, P.A., 1992. European Cenozoic rift system. Tectonophysics 208, 91-111.

Ziegler, P.A., Cloetingh, S., van Wees, J.-D., 1995. Dynamics of intra-plate compressional deformation: the Alpine foreland and other examples. Tectonophysics 252, 7-59.

\section{FIGURE CAPTION}

\section{NB: THE FOLLOWING FIGURE TO BE SPLIT BETWEEN TWO FACING PAGES WITHIN THE SECTION "The geological history of England in global context". THE FIGURE FILES ARE LABELLED FIGURE 1 PART 1 AND FIGURE 1 PART 2}

Figure 1. Simplified global palaeogeographical maps for key intervals of geological time discussed in this special issue, with the position of England indicated (red spot) and photos showing some of the characteristic evidence for geological processes operating during the time period. Palaeogeographical maps based on Scotese (2016) hosted at EarthByte (https://www.earthbyte.org/). Map labelling based on Torsvik 
and Cocks (2017) and http://scotese.com/earth.htm. Key: orange=terrestrial; white=ice sheet; pale blue=shallow water; dark blue=ocean. (i) Ediacaran sea floor, Charnwood Forest, BGS image no.: P783439; (ii) Devonian pillow lavas near Newton Abbot reflecting marine volcanic activity along the margin of the Rheic Ocean, BGS image no.: P211164; (iii) Carboniferous Lycopod tree roots, BGS image no.: P206458; (iv) Triassic Sherwood Sandstone, Nottingham, BGS image no.: P550449; (v) Early Jurassic (Toarcian) organicrich mudstones, Yorkshire; image courtesy of N. Thibault; (vi) Sussex coast Chalk cliffs, BGS image no.: P603876; (vii) The 'Lulworth Crumple' associated with Miocene inversion of the Purbeck - Isle of Wight Fault Zone, BGS image no.: P005799; (viii) DSM elevation model of part of Northumberland (between Newcastle and Morpeth) showing the development of glacially-streamlined bedforms within the landscape. The landforms were formed during the last glaciation of the region (the Late Devensian) and their morphology is partly bedrock (Carboniferous) controlled. NEXTMap Britain elevation data derived from Intermap Technologies; (ix) Ratcliffe Power Station, Nottinghamshire, BGS image no. P756684. 


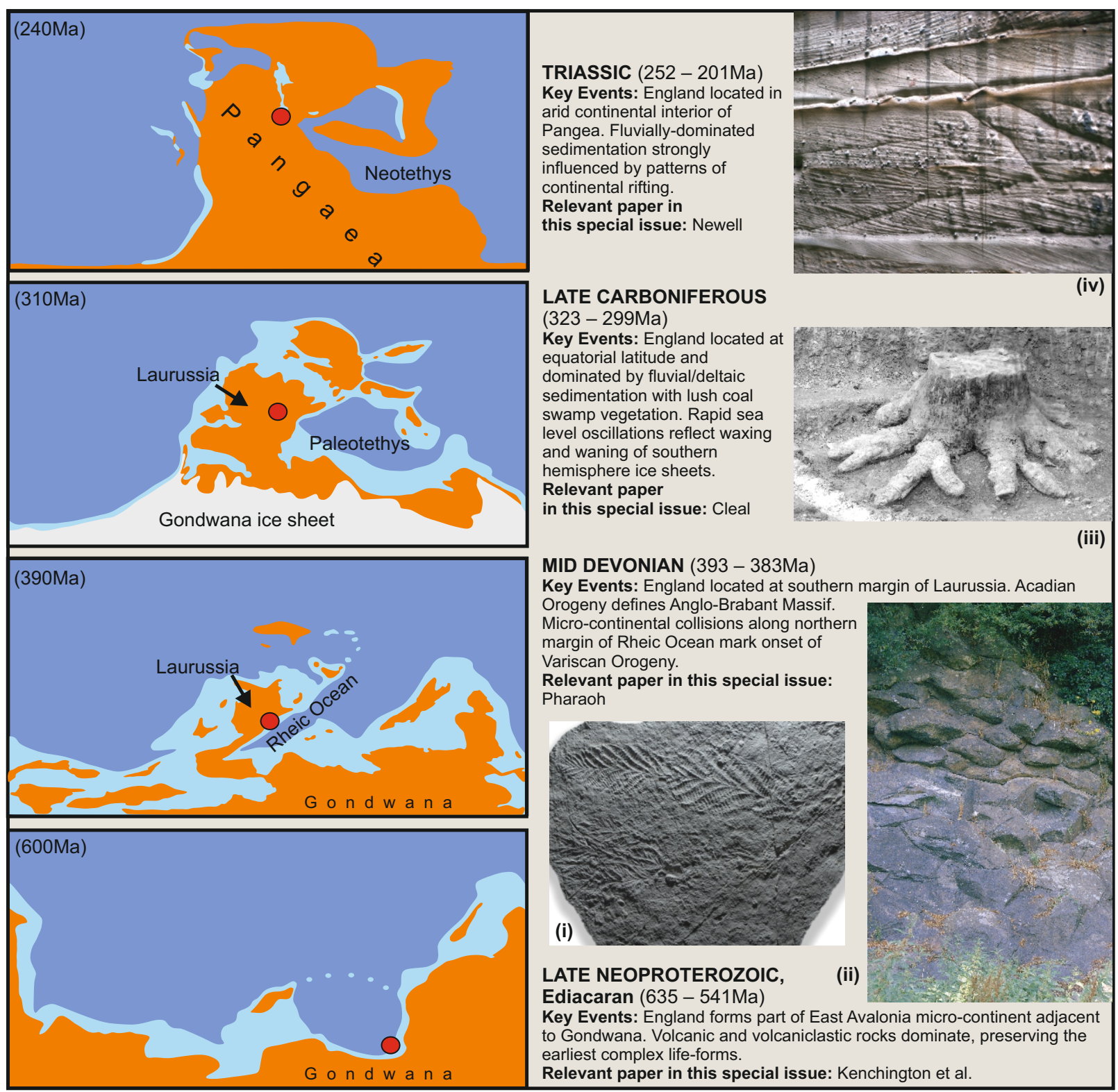



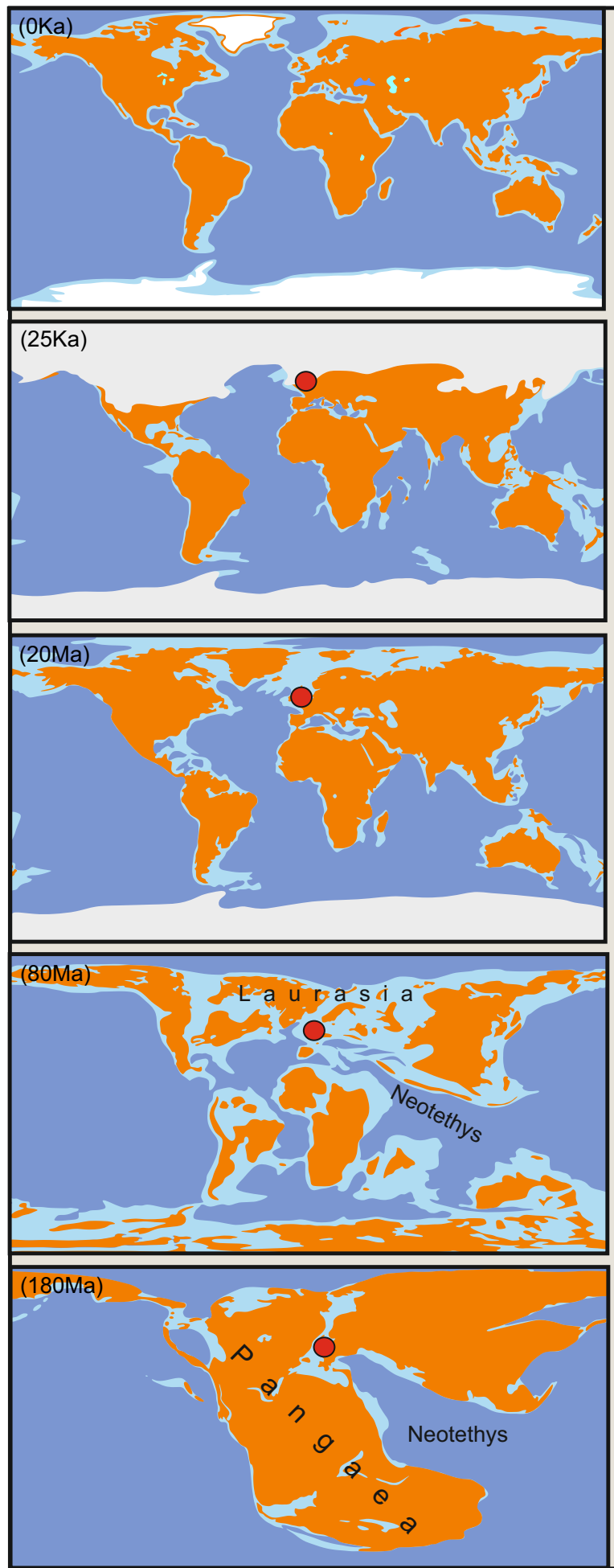

ANTHROPOCENE (?0.07 -

OKa)

Key Events: Modification of

landscape through agriculture

mining and construction, and

atmospheric composition from

burning of fossil fuels; novel

materials (e.g. concrete, plastics)

and pollutants (e.g. radionuclides)

found widely in natural systems;

changes in species distributions and

increasing rates of extinction.

Relevant papers in this special

issue: Zalazeiwicz et al.;

Brown et al.

QUATERNARY (2.59Ma - 0Ma)

Key Events: Frequent climate

oscillations (glacial/interglacial)

forced by Milankovitch cyclicity.

Climate-driven denudational isostasy

becomes the main mechanism of

landscape evolution.

Relevant paper in this special issue: Lee et al.

\section{MIOCENE (23 - 5Ma)}

Key Events: Culmination of

Alpine Orogeny. Structural

inversion along Variscan

lineaments associated with

general uplift and denudation of

England. Closure of Panama

Isthmus and beginning of

modern ocean circulation

patterns.

Relevant papers in this

special Issue: Westhead et al.;

Lee et al.

\section{LATE CRETACEOUS}

$(100-66 \mathrm{Ma})$

Key Events: All-time sea level

high associated with high

spreading rates at mid-ocean

ridges. Much of England blanketed

in Chalk with slumps, slides and

anomalous facies reflecting

periodic tectonic disruption.

Relevant papers in this

special issue:

Mortimore; Gale \& Lovell

\section{EARLY JURASSIC}

(201-174Ma)

Key events: England forms part of a sub-tropical

archipelago on the northern margin of the Tethys Ocean.

Mudstone and limestone

dominated deposition with

pronounced period of marine

anoxia in Toarcian.

Relevant paper in this

special issue:

Thilbault et al.

(vi)

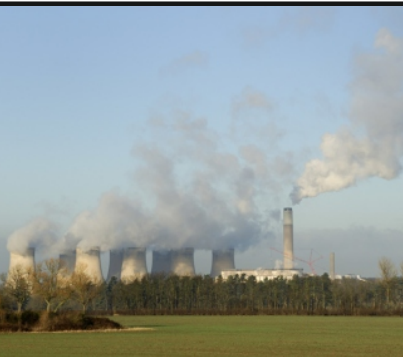

(ix)

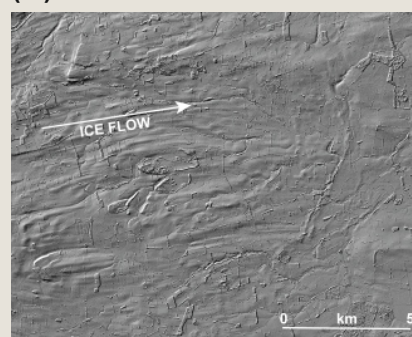

(viii)
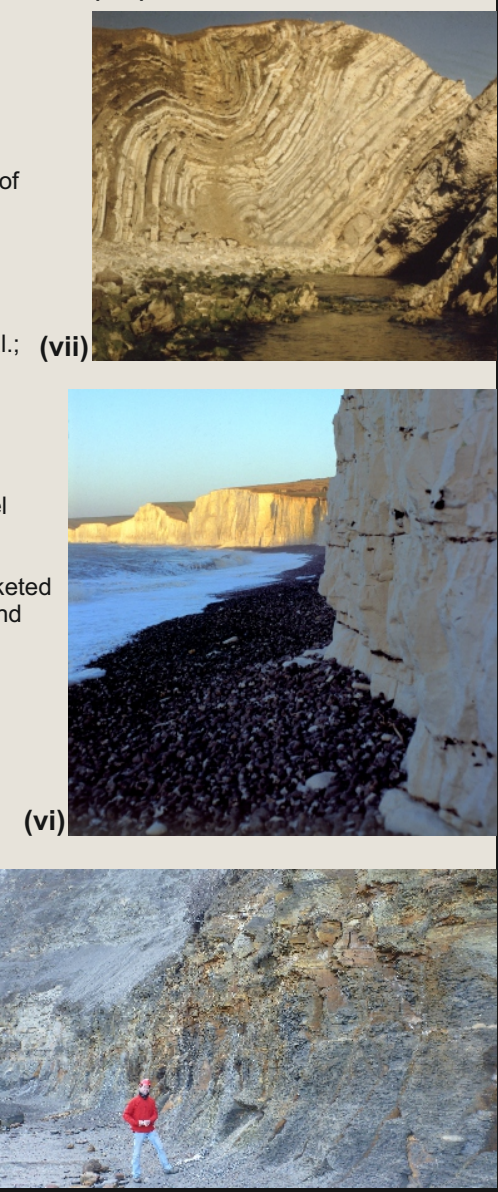